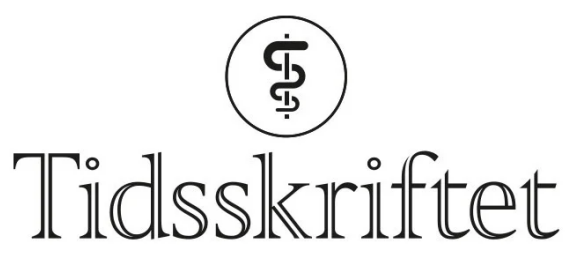

DEN NORSKE LEGEFORENING

\title{
Kirurgisk behandling av rastløse bein er utbredt og effektivt
}

KOMMENTAR

\section{ALFRED ARVESEN}

alfarve@online.no

Alfred Arvesen er overlege, spesialist i karkirurgi og generell kirurgi hos Aleris.

\section{PER HENRIK ZAHL}

Ingen av forfatterne har oppgitt noen interessekonflikter.

Bjorvatn og medarbeidere (1) har publisert en spørreundersøkelse av 2634 pasienter som ventet på legetime hos sin fastlege og finner at rundt $14 \%$ oppfyller kriteriene for diagnosen rastløse bein. Rundt 45 \% rapporterte at symptomene var moderate til veldig plagsomme, men bare 14 \% ble medikamentelt behandlet. Bjorvatn og medarbeidere konkluderer med at kunnskapen om rastløse bein er lav hos helsepersonell og at tilstanden trolig er farmakologisk underbehandlet (1). I en ledsagende lederartikkel omtales rastløse bein som et folkehelseproblem.

I denne studien er rastløse bein signifikant assosiert med kronisk muskel- og ryggsmerte (justert $\mathrm{OR}=2,06)$, irritabel tarm $(\mathrm{OR}=1,73)$ og litt mindre med kronisk utmattelse $(\mathrm{OR}=1,48)$. I diskusjonen leser vi videre at rundt halvparten av pasientene rapporterer smertefulle kriblinger mer enn bare ubehagelig kribling (므).

Karkirurger møter ofte slike pasienter. Godt over $20 \%$ av den voksne befolkning har variser (3). Overfladisk venøs insuffisiens er i stor grad genetisk betinget. Høyde og 30 loci på kromosom 1 er uavhengige risikofaktorer. Veneklaffesvikt i vena saphena magna og -parva, samt insuffisiente perforanter fører til venøs refluks og venøs hypertensjon. Vanlige symptomer er spreng- og tyngdefølelse i legg, nattlig uro, krampetendens, ofte i kombinasjon med utvikling av intermitterende eller kronisk venøst ødem. Noen utvikler hudkløe, pigmentering, venøst eksem og venøse sår.

Det er gjort mye og interessant karkirurgisk forskning på området. Allerede i 1995 rapporterte Kanter 72 \% effekt på rastløse bein symptomene 2 år etter behandling med skleroterapi (4). Venøse sidegrener tømmer seg fra det laterale subdermale plexus (LSP) og inn i «the Vein of Albanese». Shah (5) rapporterte nylig at venøs refluks i laterale subdermale plexus på utsiden av legg, kne og distale lår, var høyt korrelert med rastløse bein og/eller nattlige leggkramper i en studie med 510 pasienter. Godt over $60 \%$ av pasientene hadde unormale laterale subdermale plexus på ultralyd, og av de 241 som ble 
behandlet med ultralydassistert skumsklerosering, var hele 92 \% symptomfrie etter 1 år. I tillegg kommer den kosmetiske effekten på hud og leggsår som de primært ble behandlet for.

For karkirurger er det hverdagen å møte slike pasienter og observere god effekt av endovenøs ablasjon eventuelt skumsklerosering. Det er altså god dekning for å anbefale at pasienter med rastløse bein og overfladisk venøs insuffisiens behandles med metoder som endovenøs laserablasjon (EVLA) etter påvisning av venøs insuffisiens med fargedupleks, altså ultralyd som avdekker venøs refluks.

Statistisk signifikant komorbiditet i Bjorvatn og medarbeidere (11) kan også representere ren konfundering. Det foreligger mye kunnskap om patofysiologi ved venøs hypertensjon i underekstremitetene, konsekvenser for nevrovaskulær regulering av mikrosirkulasjon som kan forklare deres funn. Rygg- og muskelsmerter, økt trettbarhet eller depresjon kan føre til immobilisering og nedsatt bruk av de seriekoblede venepumpe-systemene i underekstremitetene. Selv en utspent tykktarm kan gi økt intraabdominalt trykk og forverre en kronisk venøs insuffisiens. Bakenforliggende ukjent dyp venetrombose (DVT) er også en viktig årsak til venøs insuffisiens. Internasjonalt er det stor uro for at Covid-19pandemien kan forverre dette, spesielt hos eldre, som overlever lungekomplikasjonene.

Vi mener altså det er godt belegg for å hevde at pasienter med rastløse bein er en sammensatt gruppe hvor både venøs og arteriell insuffisiens bør vurderes grundig før man definerer dette som nevropati eller tilstand uten kjent årsak. Det kan godt tenkes at tilstanden er kirurgisk (og ikke farmakologisk) underbehandlet.

\section{LITTERATUR}

1. Bjorvatn B, Wensaas KA, Emberland KE et al. Rastløse bein - en studie fra allmennpraksis. Tidsskr Nor Legeforen 2021; 141. doi: 10.4045/tidsskr.21.0333. [PubMed][CrossRef]

2. The international classification of sleep disorders. 3. utg. Darien, IL: American Academy of Sleep Medicine, 2014 .

3. Hamdan A. Management of varicose veins and venous insufficiency. JAMA 2012; 308: 2612-21. [PubMed][CrossRef]

4. Kanter AH. The effect of sclerotherapy on restless legs syndrome. Dermatol Surg 1995; 21:328-32. [PubMed][CrossRef]

5. Shah S. Study establishes association between reflux of lateral subdermic plexus and restless leg syndrome. https://venousnews.com/reflux-lateral-subdermic-plexus-restless-leg-syndrome/ Lest 16.11.2021.

Publisert: 13. desember 2021. Tidsskr Nor Legeforen. DOI: 10.4045/tidsskr.21.0815

(C) Tidsskrift for Den norske legeforening 2023. Lastet ned fra tidsskriftet.no 26. april 2023. 